\title{
Primary socialization in the process of professional choice and identity of nurses: a Dubarian approach
}

\author{
Socialização primária no processo da escolha e identidade profissional da enfermeira: uma abordagem Dubariana
}

Socialización primaria en el proceso de elección e identidad profesional de la enfermera: un abordaje Dubariano

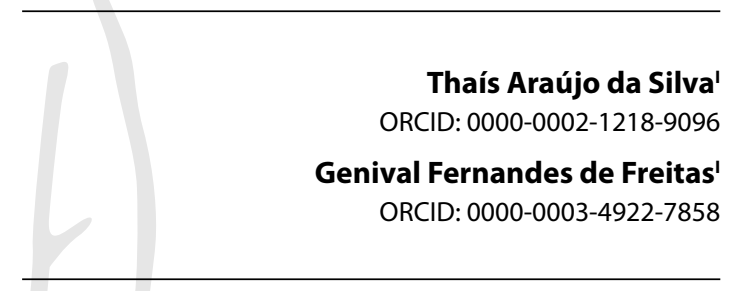

'Universidade de São Paulo. São Paulo, São Paulo, Brazil.

How to cite this article:

Silva TA, Freitas GF. Primary socialization in the process of professional choice and identity of nurses: a Dubarian approach. Rev Bras Enferm. 2021;74(2):e20200293. https://doi.org/10.1590/0034-7167-2020-0293

\section{Corresponding author:}

Thaís Araújo da Silva E-mail: taarsi2@hotmail.com

EDITOR IN CHIEF: Dulce Barbosa ASSOCIATE EDITOR: Rafael Silva

Submission: 06-03-2020

Approval: $12-21-2020$

\section{ABSTRACT}

Objectives: to analyze the experiences of management nurses over the primary socialization process that contributed to their professional choice and identity. Methods: qualitative and explanatory study grounded in Dubar's theory, carried out with 11 management nurses. Semistructured interviews were conducted, transcribed, and categorized by applying discourse analysis. Results: the motivations for the professional choice and identity of management nurses were found. They were related to family influence in childhood, nursing representations, perception of care practices experienced in a health-related situation in the family, choice of nursing given its academic titles, lack of knowledge about the nursing profession, and assertive choice of this profession. Final Considerations: professional choice was closely linked to initial social processes in people's lives and the idea of a socially and uniquely built professional identity. Descriptors: Socialization; Career Choice; Social Identification; Ego; Nursing.

\section{RESUMO}

Objetivos: analisar as experiências e as vivências de enfermeiras gestoras, durante o processo de socialização primária, que contribuíram para a escolha e identidade profissional. Métodos: estudo qualitativo e exploratório ancorado na teoria de Dubar, realizado com 11 enfermeiras gestoras. Foram realizadas entrevistas semiestruturadas as quais foram transcritas e categorizadas com o apoio da Análise do Discurso. Resultados: desvendaramse as motivações para a escolha e identidade profissional da enfermeira gestora, as quais se concatenaram às influências familiares na infância, às representações da Enfermagem, à percepção das práticas cuidativas vivenciadas em uma situação de necessidade de saúde na família, à escolha pela Enfermagem pela titularidade, ao desconhecimento da profissão de Enfermagem e à escolha assertiva pela profissão de Enfermagem. Considerações Finais: a escolha profissional está essencialmente interligada aos processos sociais iniciais da vida do indivíduo e inter-relaciona-se com a ideia de uma identidade profissional construída social e singularmente.

Descritores: Socialização; Escolha da Profissão; Identificação Social; Ego; Enfermagem.

\section{RESUMEN}

Objetivos: analizar las experiencias y vivencias de enfermeras gestoras durante el proceso de socialización primaria que contribuyeron a la elección y a la identidad profesional. Métodos: estudio cualitativo, exploratorio, fundamentado en la teoría de Dubar, realizado con 11 enfermeras gestoras. Fueron realizadas entrevistas semiestructuradas, que se transcribieron y categorizaron según el Análisis del Discurso. Resultados: se vislumbraron las motivaciones de elección e identidad profesional de la enfermera gestora, que se concatenaron con las influencias familiares de la infancia, las representaciones de la enfermería, la percepción de las prácticas de cuidado experimentadas en situaciones de necesidad de salud familiary la elección asertiva de la profesión de enfermería. Consideraciones Finales: la elección profesional está esencialmente intervinculada a los procesos sociales iniciales de la vida del individuo, y se interrelaciona con la idea de una identidad profesional construida de manera social e individual. Descriptores: Socialización; Selección de la Profesión; Identificación Social; Ego; Enfermería. 


\section{INTRODUCTION}

The term socialization emerged in the sociology field, and its meaning focuses on the accumulation of processes related to social, experiential, and sui generis attitudes ${ }^{(1)}$. Considered a complex phenomenon, socialization can be split into two structures. The first, known as objective, deals with behavioral reactions observed from the outside. The second, named subjective, encompasses the feelings of success and adaptation experienced under the society conditions ${ }^{(1)}$.

The identity of an individual is the product of numerous socializations over their life ${ }^{(2)}$. Culture, symbols, and sense of belonging, among other factors, gradually contribute to building personal and collective identities ${ }^{(3)}$.

Professional identity is consolidated, according to Dubar ${ }^{(4)}$, when the individual enters the job market. However, the sociative elements originating in the first phase, named primary socialization, are important aspects for professional choice, since it begins when the individual is born ${ }^{(4)}$. The socialization process substantially contributes to making up a professional identity that translates into the dialectical relationships between individuals and the context in which they are inserted ${ }^{(5)}$.

In postindustrial societies, many studies have been developed on professional identity, given that work scenarios and contexts have gone through several changes over time $\mathrm{e}^{(6-7)}$, especially after the 1970 s, as a consequence of capitalism ${ }^{(7)}$. From this perspective of transformations in the world of work and professions, changes in the nursing field can be perceived and they shape identity nuances in the category, including those related to the nurse professional identity. Studies have shown that identity genesis in nursing resulted from the milestone that the professionalization of the field was, instituted by the precursor of modern nursing, Florence Nightingale ${ }^{(2,5,89)}$, who brought up the idea of an identity based on vocation, dedication, obedience, abnegation ${ }^{(2,9)}$, and subservience ${ }^{(10)}$.

Among the several Brazilian and international milestones in nursing, some changes stood out in Brazilian nursing, especially regarding the identity of the profession, resulting, among other factors, from environmental and sociological variations present in society over history ${ }^{(10)}$. Studies have addressed the subject of professional identity in nursing ${ }^{(11-13)}$, and 2020 was chosen as the International Year of the Nurse and the Midwife ${ }^{(14)}$. Nevertheless, in face of the current pandemic caused by the new coronavirus, new discussions about the representation and the image of this profession have emerged ${ }^{(15-16)}$. These circumstances lead to a syllogism regarding the discussion on the unique nuances of professional identity from the perspective of nurses from different contexts and settings.

The present study had, as its research objects, the heterogeneous experiences that contributed to the professional choice and identity described in accounts of management nurses at the Department and Division of Nursing at the University of São Paulo Hospital, who were included in the Teaching-Care Integration Program, executed as part of a partnership between the teaching hospital of the University of São Paulo and the University of São Paulo School of Nursing.

The choice of the social group mentioned above is compatible with the subject of professional choice and identity in nursing, since the participants of the present study and the settings (the teaching hospital of the University of São Paulo and the University of São Paulo School of Nursing) are considered a reference model for other Brazilian contexts that experience the teaching-service process, because they are a gold standard, and this characteristic strongly impacts professional choice and identity. Studies have inferred that discussing this subject offers the possibility of reflecting on the struggles and victories toward an ideal image of the nurse inserted into society, envisioning achieving rights, autonomy, credibility, and better working conditions ${ }^{(17-19)}$.

From this perspective, the following questions arose: What were the experiences over the primary socialization process that contributed to the professional choice of management nurses? In which way did the perceptions and meanings resulting from these experiences contribute to the formation of the professional identity of nurses as professional agents?

\section{OBJECTIVES}

To analyze the experiences of management nurses over the primary socialization process that contributed to their professional choice and identity.

\section{METHODS}

\section{Ethical aspects}

The present study met human research ethical principles, according to the Brazilian National Health Council Resolution no. 466, of December 12, 2012. The proposal was submitted to the Research Ethics Committee of both the teaching hospital of the University of São Paulo and the University of São Paulo School of Nursing. Anonymity of the participants was guaranteed, and they were characterized as follows: P1, P2, P3 etc.

\section{Theoretical-methodological framework}

The present study was grounded in the theory of sociologist Claude Dubar, who devoted himself to studying work sociology to try to elucidate the identity construction process in people inserted in different knowledge fields.

According to this author, developing an identity begins at birth. During childhood, several interactions gather standards of how to live in society, which can happen in the family, at school, at church, at university, and in other important nuclei. The inheritance offered to the individual in this first phase, known as primary socialization, sticks to the concepts of morals, ethics, and instrumentals of individuals in the different knowledge fields ${ }^{(1)}$.

Primary socialization ends when the individual enters the world of work, and, at this point, secondary socialization begins. However, all the background developed over the first cycle will strongly impact the second phase. A continuity or a rupture is common during the transition, since the individual, now also a professional, experiences other scenarios and by biographical shocks that induce them to belong to groups considered reference. However, sometimes, this moment can cause people to go through identity crises, which brings about questions regarding their professional choice ${ }^{(4)}$. 
In this conceptual trajectory about the identity construction of an individual, Dubar defines identity as a"result both stable and provisional, individual and collective, subjective and objective, biographic and structural, of the various socialization processes which, as a whole, build individuals and defines institutions", which means that identities can change over life as the individual integrates into reference groups ${ }^{(1)}$.

\section{Study type}

This was a qualitative and exploratory study, developed according to the principles of the Consolidated Criteria for Reporting Qualitative Research, made up of 32 items that aim to ensure rigor in study design ${ }^{(20)}$.

\section{Methodological procedures}

\section{Study setting}

The present study was carried out at the teaching hospital of the University of São Paulo and the University of São Paulo School of Nursing.

The teaching hospital of the University of São Paulo is a general one, coordinated with the Brazilian Unified Health System (SUS, as per its acronym in Portuguese), inserted in the Center-West Regional Health Coordinating Office, and has 258 hospital beds. Serves students, professors and technical and administrative employees at the University of São Paulo, and the population geographically inserted in the Butantã SUS Health District ${ }^{(21)}$.

The Department of Nursing at the teaching hospital of the University of São Paulo is the highest body of nursing in this hospital's flowchart and its main function is to supervise the nursing activities carried out at that hospital. It encompasses five divisions: Clinical Nursing, Surgical Nursing, Pediatric Nursing, Obstetrics and Gynecology, and External Patients ${ }^{(21)}$.

The University of São Paulo School of Nursing, founded in 1942 , is located in the western zone of the city of São Paulo, at the Health/Law Quadrilateral, and has the objective of achieving excellence in education, research, and extension ${ }^{(21)}$.

\section{Data source}

The inclusion criteria were: nurses working as a professor at the University of São Paulo School of Nursing who concomitantly worked in the directorship of the Department of Nursing at the teaching hospital of the University of São Paulo; and management nurses at the Division of Nursing of the teaching hospital of the University of São Paulo, and subsequently working as professors at the Department of Professional Orientation at the University of São Paulo School of Nursing, where the subject Management in Nursing is offered.

The choice of participants occurred by consulting documents of both organizations and by contacting professionals of these places who worked in the established period (from 1978 to 2015), so participants could be indicated.

It is important to stress that the choice of the starting year of the examined period as 1978 was justified by the fact that the teaching hospital began offering obstetric, pediatric, and emergency care, among others, full-time in that year. The year 2015 was chosen as the end of the analyzed period because the teaching hospital was threatened with being disconnected from the University of São Paulo School of Nursing.

By using these methods, 12 nurses who worked as managers at the hospital or as professors at the School of Nursing between 1978 and 2015 were invited, in person or by e-mail. However, one of them did not participate in the study because she was not located.

It is important to mention that eight out of the 11 participants were both managers at the Department of Nursing and professors at the School of Nursing, concomitantly. The others worked as managers at the Division of Nursing and became professors at the Department of Professional Orientation afterwards.

\section{Data collection and organization}

Data were collected by applying an instrument designed by the authors that contained semi-structured questions based on Dubar's theory, which addressed life trajectory, professional identity, and professional choices. The data collection technique was also grounded in the Thematic Oral History methodology, because it met the study objectives. This method aims to show the conceptions of individuals on a specific subject ${ }^{(22)}$.

Data collection occurred by interviewing the participants who wanted to freely be part of the study, at their preferred place and time, from March to November 2017. Each interview lasted around 35 minutes.

\section{Data analysis}

The material obtained with the interviews, properly recorded, transcribed (the interviews were transcribed literally, including grammar mistakes and language vices), transcreated (the narratives were formatted so the texts were considered adequate and high-quality), and validated (by means of the approval of the participants, communicated by e-mail) ${ }^{(23)}$, resulted in discursive texts that were submitted to discourse analysis, a method focused on producing meanings from the relationship between language, subject, society, and history to understand ideologies present in the core of the discourses. The steps of this type of analysis are the three levels of the meaning-generating path: fundamental, narrative, and discursive ${ }^{(24)}$. The first phase (fundamental) established the semantic categories present in the text ${ }^{(24)}$, that is, the authors observed the relationships and the meanings between the words in the participants' narratives about professional choice and identity in nursing. In the second step (narrative), the authors paid attention to the narrative roles played by subjects and objects, which were expressed by desire, duty, power, knowledge, and values ${ }^{(24)}$ related to the study theme (professional choice and identity). In the last step (discursive), the abstract forms of the narrative level materialized ${ }^{(24)}$, that is, the authors understood the intentions contained in the ideology and symbology pervading the participants' accounts on professional choice and identity.

Six categories emerged from this analysis: family influences in childhood, nursing representations, perception regarding care 
practices experienced in a health need situation in the family, nursing for academic titles, lack of knowledge of the nursing profession, and nursing as a conviction.

\section{RESULTS}

Six categories expressed the motivations and influences the participants experienced that contributed to professional choice and identity over primary socialization. The first, family influences in childhood, showed the participants' experiences about care originating in the bosom of the family, as observed in the statements of respondents $\mathrm{P} 2$ and $\mathrm{P}^{(21)}$ :

My father gave me a doll with pottery head and limbs. On the very first days after getting it, it fell and one of its legs broke. Mydad made a wood leg, and I did the "dressing" on it every day, making sure that the wood in the "prosthesis" did not show. That was my first "care" experience, and I think it steered my professional interests. (P2)

My professional choice probably resulted from my own history. Until the age of 11, my health demanded care, whether from doctors, who, at that time, provided home care, or from professionals from small hospitals [...], or from my mom, who devoted to take care of me full time. Back then, sick people were cared for in the truest sense of the term. Additionally, my mom's constant affection and presence made the meaning of caring be part of my cultural universe. Since then, I have been feeling that caring and serving were verbs I would like to conjugate in my life. (P3)

The second category, nursing representations, put across that the professional choice for this area occurred as a consequence of the identification of being a nurse in society, by means of the relationship with other people and organizational institutions, as observed in the statements of respondents P4, P6, P9 and P1 $11^{(21)}$ :

The choice happened by accident, because I liked biology. My friend's dad told us he had seen an interview saying that Brazil really needed nurses. So, it was a choice with deliberation, in the sense that I heard an opinion and opted to enter the nursing field. (P4)

Before college, I visited Ohio and got to know the University of Toledo. There was an extraordinary undergraduate nursing course there, with autonomy and independence. I got back to Brazil and applied for a place in nursing undergraduate courses. (P6)

I started my undergrad nursing course in 1982 [...]. What really caught my attention back then was that the course was entitled nursing and obstetrics. I have always had great interest in the maternal-child area. So, after I got my degree, I got a specialization and did other courses in the area of obstetrics and neonatology. (P9)

I observed the identity of the nurse by means of a friend of my sister's, who was a nurse. So I applied for a place at college in the health area and got into a nursing course. (P11)

The third category, perception regarding care practices experienced in a health need situation in the family, indicated that the choice of nursing resulted from the experience of a critical episode of development of a disease in their family, as observed in the statements of respondents $\mathrm{P} 1$ and $\mathrm{P} 10^{(21)}$ :
I got a degree in biology. Nursing was my second choice. I chose to study nursing when my mom was stricken by a cancer. (P1)

I chose to be a nurse when I was still a teenager, when I accompanied my grandmother at my uncle's deathbed, with no support at all from the health team. I decided that I would be a health professional, with my activities oriented mostly toward humanized care, focused on the interaction with patients and their families. I opted for nursing, because I thought it would offer me this possibility. (P10)

The fourth category, nursing for academic titles, emerged from excerpts in which the participants declared that their professional option was based on occasional merit, because of the need to obtain a degree, as observed in the interviewee's speech $\mathrm{P} 5^{(21)}$ :

I had a friend who was getting a specialization in obstetrics and I thought that I would like to look after people. So I ended up migrating to this area [...]. There was a reformulation in education in 1975, and obstetricians began having the right to practice nursing. Therefore, I am a nurse because of a title, not by choice. (P5)

The fifth category, lack of knowledge of the nursing profession, exposed a professional choice influenced by other people, pervaded by a fearless conduct, as observed in the interviewee's speech $\mathrm{P7}^{(21)}$ :

I applied to medical school and went to the waiting list. So I attended a course about orthoptics at the Federal University of São Paulo and, during the interview, they told me to try to apply to the nursing course. So I did that, but questioning myself if that really was what I wanted, because of the lack of knowledge I had on the role played by nurses. (P7)

The last category, nursing as a conviction, showed a categorical and emphatic professional choice, as observed in the interviewee's speech P8 ${ }^{(21)}$ :

I was interested in dealing with people, care, and health [...]. Nursing was a choice, I had no doubt. (P8)

\section{DISCUSSION}

The results in the first category, family influences in childhood, stressed the experiences that pervaded the participants' childhood and family scenarios that contributed to choosing nursing as their profession. Family represents a sociocultural system that influences future decisions of the progeny, because it can influence the individual's personality which impacts on personal and work identity ${ }^{(1)}$

In a study carried out between 2002 and 2012, researchers interviewed seven teachers in different municipalities in the Center-West and Southeast Regions of Brazil to bring up, from these professionals' memories, the training and education received in childhood. The results showed that professional choice was connected with the female education they had been provided with $^{(25)}$.

Childhood memories showed the importance of ludic moments to professional choice ${ }^{(26)}$. In this regard, Dubar borrowed the perspective of Piagetian psychology to explain the construction of 
identity from the socialization standpoint rather than the teachinglearning process one, referring to the frequent reproduction of the roles and behaviors of the peers with whom children socialize, especially their parents ${ }^{(1)}$. Therefore, latent memory originated in delivered care that had been perceived by the participants over their life trajectories.

In the second category, nursing representations, it was noted that, over time, the social representativeness of an institution or of a profession becomes a unit of professional identity, since it is built by intertwining cultural, economic, and social aspects, as well as by the disseminating its role in mass media ${ }^{(2)}$.

The data gathered in this category related to the results of a study carried out in Primary Healthcare Units in Juiz de Fora, Minas Gerais, Brazil, that had the objective of understanding the perceptions of 12 nurses regarding acknowledgment and appreciation of the nursing profession and its implication in everyday life. It was shown that the representation of the nurse in society influenced their image. In addition, this study pointed out that professionals built their self-image based on the reflections originating in sociative pairs ${ }^{(27)}$.

The existence of a profession is established according to its jurisdiction, that is, it happens when a group of people takes over a field of knowledge and coordinates the concrete practice of work and knowledge ${ }^{(28)}$. Consequently, representations can influence the structuring and identification of jurisdictional elements of a profession and, therefore, prototypes and rules instituted by representatives (workers, systems, and organizations) can ultimately develop referential groups ${ }^{(1)}$. From this perspective, the present study sought to obtain information from the participants, who occupied teaching and management functions in two organizations that are considered gold standard in education, research, extension, and laboratory care practices. This logic substantiates the standard and reflects the continuous professional excellence that was assertively cultivated since the participants' primary socialization path concerning professional choice and identity pervaded by the influence of nursing representation in society.

The third category, perception regarding care practices experienced in a health need situation in the family, indicated care as the main predictor of the choice of nursing, especially when the accounts mentioned the presence of this factor in critical experiences in the family sphere.

A study with Brazilian and Peruvian nurses showed that one of the reasons that made them opt for nursing was related to the circumstances cited above. This finding was described from the perspective of the "servile spirit", in the sense of donation, of people who look after people, which evokes the imagery field of the nurse over the so-called preprofessional era ${ }^{(29)}$. Therefore, care would be the manifestation of the act of serving other people and can be characterized as a labor action carried out within the competences of a profession, in which this component allows the development of expertise in nursing, contributing to the construction of the foundation of the professional jurisdiction in this area.

The professionals interviewed in the present study, whose jobs put them in the position of coordinating education and practice, mentioned the perpetuation of the conduct of serving, of care, since the Teaching-Care Integration Program itself has, as one of its premises, the fulfillment of the population needs and the solution of problems originating in reality ${ }^{(30)}$.

The next category, nursing for academic titles, brought about the reflection that the act of choosing a profession because of the titles it provides can refer to a system that Dubar called identity transactions, which are established in a dynamic of continuities and discontinuities. The individual has the power to decide whether they incorporate norms, values, and the knowledge built or idealized over primary socialization. People allow themselves to embody a perceived identity, which is defined as "a projection of themselves in the future, the anticipation of a job trajectory, and the formulation of a logic of learning, or, even better, of training"(1). Additionally, academic knowledge and claiming of privileges by people inserted in varied professional jurisdictions structure and reinforce professional identity.

Still regarding this category, it is important to emphasize that the incorporation of a profession by another occurred as professionals seized the opportunity available in this situation, since granting obstetricians the right of practicing nursing resulted from transformations in the guidelines of the former, proposed in the 1968 University Reform, strengthening the internalization of professional norms, values, and knowledge $\mathrm{e}^{(1)}$.

The fifth category, lack of knowledge of the nursing profession, showed findings that corroborated the conclusion of a study that also addressed the lack of knowledge of society regarding the functions of a nurse. This study was carried out in a public university in the city of Campinas, São Paulo, Brazil, with eight students who were completing high school at public schools and attended the Interdisciplinary Higher Training Program ${ }^{(31)}$.

An aspect that should be emphasized regarding the topic of this category is the attempt to obtain a medical degree. Medicine is a career that has social status because of the identity and imagery standardization that represent this area. This conception has been pointed out by studies that have mentioned these ideologies developed around medicine by showing that, in current times, the same archetype surrounds the medical professional ${ }^{(2,32-33)}$ and that nursing is inserted in an attached and dispensable context. This is not new, given that the Nightingale system, since its early days, has demanded submission to the medical class when nurses were hired ${ }^{(34)}$.

Dubar portrayed the moral division of work taking into account that segregations follow hierarchization processes, as a result of social recognition of a profession or the lack of it and of the understanding that some professions are identified as sacred and/or profane ${ }^{(35)}$. Medicine would be characterized as a sacred profession, whereas nursing would be seen as profane, as a consequence of the way their professional jurisdictions, instituted by means of power relationships, were developed over the historical-social trajectory. Consequently, it can be hypothesized that being a professor and/or management nurse can confer status on the profession, since developing activities in these two branches (education and management) can lead to social recognition, especially when the professional works at renowned institutions, as in the case of the participants interviewed in the present study.

The sixth and last category, nursing as a conviction, reported the emphatic opinion of people in face of the need to choose the profession they want to have, which indicated affinity with a specific knowledge field. 
A study interviewed 21 students at three undergraduate courses (nursing, pedagogy, and administration) at two private higher education institutions in the city of São Paulo, São Paulo, Brazil, between 2015 and 2018, and concluded that the professional choice of nursing was based on conviction ${ }^{(36)}$.

Dubar analyzed that people often make their professional choices not just to obtain a degree, but because of a "personal construction of an identity strategy that mobilizes their own image, the evaluation of their capacities, and the fulfillment of their desires $^{\prime \prime(1)}$. Therefore, certainty at the time professional choice is made can be a sign of firmness in the perception of professional identity, since the attitude adopted at a specific time strengthens the chosen profession. Marked conviction stood out in the presence and participation of these women, nurses, professors, and managers, in two settings that are representative of Brazilian nursing, which contributes to motivating and persuading other people who want to get into this field.

In face of the above, it is inferred that there is the need for an ideal identity for nurses, perceived by means of identity continuities and discontinuities over history. Even two hundred years after the establishment of modern nursing, it is possible to identify the eloquence of the dialogue about the actual reasons behind the professional choice of this area and the reconstruction of the professional identity of the nurse.

\section{Study limitations}

The present study was innovative in its conception. However, it was based on the perception of a specific group of professionals who worked at the teaching hospital of the University of São Paulo and the University of São Paulo School of Nursing. Despite this characteristic, knowing the understanding of this subject by people from different settings and with different perspectives (managers and professors) who were part of a Teaching-Care Integration Program is desirable. Additionally, the study centered around a specific theory and, consequently, it would be interesting to apply or mix other theoretical frameworks that address the study object (professional choice and identity) to try to obtain new insights.

\section{Contributions to the nursing, health, or public policy areas}

The present study contributed to social visibility and recognition of the working process of management nurses at the teaching hospital of the University of São Paulo and professors at the University of São Paulo School of Nursing, impacting both the professional training area and management practices of nursing professionals, and, consequently, strengthening the consolidation of the process of professional identity construction of nurses, taking into account the Teaching-Care Integration Program context.

\section{FINAL CONSIDERATIONS}

Analysis of the experiences of nurses grounded in Claude Dubar's theory was based on the primary socialization process of these social actors and allowed to understand influences and motivations behind the professional choice and identity of nurses, acting in both the management and teaching areas.

Sharing these personal experiences, which occurred in several social scenarios cited by the participants, contributed to clarifying the subjective, historical, political, and social dimensions that intertwine with the historical imprint of the nursing profession in the institutional context of management and teaching practices in the scenario of the teaching hospital of the University of São Paulo. The reasons why the participants made their professional choice were influenced by people belonging to groups into which they were inserted, from the family nucleus to the formative and social universe. Additionally, the experiences they had over their lives contributed to the professional choice oriented toward the nursing field, including when care was perceived and translated by them as the core of the profession skills. The influences found in the present study corroborated results of other studies, especially those that addressed motivations for nursing as the target of professional choice and for the formation of its identity induced by experiences originating in family, social, historical, and political contexts.

This scenario calls for the need to provide nurses with an ideal identity and stir up new discussions about the addressed subject, with the purpose of emerge unfolding about professional choice and identity in nursing, taking into account the various experiences during primary socialization, which can impact the professionals' work in the future, attracting autonomy and social visibility.

From this perspective, professional choice is closely interrelated to initial social processes in the life of the individual and interconnects with the idea that professional identity is built socially and uniquely and that scenarios and experiences are determining for professional choice to be made with autonomy and consciousness.

\section{FUNDING}

This is a research funded by the Coordination of Support for Higher Education Personnel (CAPES), through a doctoral scholarship in the country and abroad.

\section{ACKNOWLEDGMENT}

We thank Tatiana Araújo de Albuquerque and Tamara Araújo dos Santos for their assistance in revision this research.

We thank the participants who made this work possible.

\section{REFERENCES}

1. Dubar C. A socialização: construção das identidades sociais e profissionais. São Paulo: Martins Fontes; 2005.331 p.

2. Teodósio SSC, Padilha MI. "To be a nurse": a professional choice and the construction of identity processes in the 1970s. Rev Bras Enferm. 2016;69(3):428-34. https://doi.org/10.1590/0034-7167.2016690303i 
3. Almeida MCO, Vale CS, Silva CCG. Building the identity of the student in the face of the gender ideology. Div Journal. 2020;5(1):603-14. https://doi.org/10.17648/diversitas-journal-v5i1-1004

4. Dubar C. A crise das identidades: a interpretação de uma mutação. São Paulo: Universidade de São Paulo; 2009. 269 p.

5. Guisardi PJ, Oliveira MAC. Socialization of nurses in the Family Health Strategy: contributions to professional identity. Rev Bras Enferm. 2019;72(suppl 1):17-23. https://doi.org/10.1590/0034-7167-2016-045

6. Coutinho MC, Krawulski E, Soares DHP. [ldentity and work in contemporaneousness: re-thinking the possible articulations]. Psicol Soc. 2007;19(esp 1):29-37. https://doi.org/10.1590/S0102-71822007000400006 Portuguese.

7. Antunes R. Desenhando a nova morfologia do trabalho no Brasil. Estud Av. 2014;28(81):39-53. https://doi.org/10.1590/ S0103-40142014000200004

8. Almeida DB, Silva GTR, Queirós PJP, Freitas GF, Laitano ADC, Almeida SS, et al. Portuguese nursing: history of the life and activism of Maria Augusta Sousa. Rev Esc Enferm USP. 2016;50(3):498-504. https://doi.org/10.1590/S0080-623420160000400017

9. Figueiredo MAG, Peres MAA. The identity of the female nurse: a reflection from the perspective of Dubar. Rev Enf Ref. 2019;serlV(20):149-54. https://doi.org/10.12707/RIV18079

10. Silva TA, Freitas GF, Takashi MH, Albuquerque TA. Professional identity of nurses: a literature review. Enferm Glob. 2019;18(2):563-600. https://doi.org/10.6018/eglobal.18.2.324291

11. Teodósio SSC, Padilha MI. [Nurses' training and the (re)construction of their professional identity (1970s)]. Rev Enferm UERJ. 2018;26:e20054. https://doi.org/10.12957/reuerj.2018.20054 Portuguese.

12. Fernandes MC, Silva LMS, Silva MRF, Torres RAM, Dias MAS, Moreira TMM. Identity of primary health care nurses: perception of "doing everything". Rev Bras Enferm. 2018;71(1):142-7. https://doi.org/10.1590/0034-7167-2016-0382

13. Helder H. Training and professional identity: encouragement to investigate the history of nursing. Acta Paul Enferm. 2018;31(4):3-5. https:// doi.org/10.1590/1982-0194201800047

14. Kennedy MS. Nurses: courageous, committed, and fed up. Am J Nurs. 2020;120(6):7. https://doi.org/10.1097 / 01.NAJ.0000668648.29477.e1

15. Howard C. Nursing in the COVID-19 pandemic and beyond: protecting, saving, supporting and honouring nurses. Int Nurs Rev. 2020;67(2):157-9. https://doi.org/10.1111/inr.12593

16. Einboden R. SuperNurse? troubling the hero discourse in COVID times. Health (London). 2020;24(4):343-7. https://doi. org/10.1177/1363459320934280

17. Silva AR, Padilha MI, Backes VMS, Carvalho JB. Professional nursing identity: a perspective through the Brazilian printed media lenses. EsC Anna Nery. 2018;22(4):e20180182. https://doi.org/10.1590/2177-9465-ean-2018-0182

18. Almeida RLM, Rodrigues AAP, Tarma GF, Figueiredo MAG, Almeida Filho AJ, Santos TCF, et al. Clothing and professional identity in the training of nurses in the city of Juiz de Fora. Rev Bras Enferm. 2018;71(suppl 4):1548-55. https://doi.org/10.1590/0034-7167-2017-0522

19. Costa CGS, Vieira DVF, Martins LHFA, Castro Jr AR. Professional image construction in Ceará: the nurse on the modifications in the professional record scenario. Cad Saúde Colet. 2019;27(2):166-71. https://doi.org/10.1590/1414-462×201900020116

20. Tong A, Sainsbury P, Craig J. Consolidated criteria for reporting qualitative research (COREQ): a 32-item checklist for interviews and focus groups. Int J Qual Health Care. 2007;19(6):349-57. https://doi.org/10.1093/intqhc/mzm042

21. Silva TA. [The professional identity of the nurse manager of the Teaching Care Integration Program (1978 - 2015)] [These] [Internet]. Universidade de São Paulo, Escola de Enfermagem 2019[cited 2020 May 30]. 235 p. Available from: https://www.teses.usp.br/teses/ disponiveis/7/7140/tde-04032020-153420/pt-br.php Portuguese.

22. Macêdo MLAF, Costa MCMDR, Lima SP, Padilha MI, Borenstein MS. Thematic Oral History in nursing research: a bibliometric study. Cogitare Enferm. 2014;19(2):384-91. https://doi.org/10.5380/ce.v19i2.37360

23. Meihy JCSB, Holanda F. História Oral: como fazer, como pensar. São Paulo: Contexto; 2019, 176 p.

24. Fiorin JL. [Two concepts of enunciation]. Estud Semiót. 2020;16(1):122-37. https://doi.org/10.11606/issn.1980-4016.esse.2020.172329 Portuguese.

25. Sarat M, Campos MI. Memories of childhood and education: eliasian approaches on women. Educ Real. 2017;42(4):1257-77. https://doi. org/10.1590/2175-623664283

26. Wajskop G. [Children's oral language and literacy play in day care centers]. Educ Real. 2017;42(4):1355-74. https://doi.org/10.1590/2175623661980 Portuguese.

27. Lage CEB, Alves MS. [Evaluation of nursing and implications in nurses' daily routine]. Enferm Foco (Brasília). 2014;7(3/4):12-6. https://doi. org/10.21675/2357-707X.2016.v7.n3/4.908 Portuguese.

28. Abbot A. Processual Sociology. Chicago: University of Chicago Press; 2016. 336 p.

29. Ribeiro AAA, Falcon GS, Borenstein MS, Padilha MICS. [Professional choice and the social imaginary: Brazilian and Peruvian nurses]. Esc Anna Nery. 2006;10(2):241-50. https://doi.org/10.1590/S1414-81452006000200011 Portuguese.

30. Baldoino AS, Veras RM. Analysis of Service-learning activities adopted in health courses of Federal University of Bahia. Rev Esc Enferm USP. 2016;50(spe):17-24. https://doi.org/10.1590/S0080-623420160000300003 
31. Pierrotti VW, Guirardello EB, Toledo VP. Nursing knowledge patterns: nurses' image and role in society perceived by students. Rev Bras Enferm. 2020;73(4):e20180959. https://doi.org/10.1590/0034-7167-2018-0959

32. Matos MS, Ferraço CM, Rosa JCA, Bastos JA, Brandão PC. [First semester in medical school: reality shock and the beginning of acquisition of physician's professional identity]. Rev Psicol Saúde. 2019;11(3):157-71. https://doi.org/10.20435/pssa.v0i0.660 Portuguese.

33. Martins JB, Rodriguez FP, Coelho ICMM, Silva EM. [Factors that influence the choice of medical specialty by medical students of an Educational Institution in Curitiba (PR)]. Rev Bras Educ Méd. 2019;43(2):152-8. https://doi.org/10.1590/1981-52712015v43n2rb20180158 Portuguese.

34. Santos SC, Almeida DB, Silva GTR, Santana GC, Silva HS, Santana LS. The professional identity of female nurses: an integrative review. Rev Baiana Enferm. 2019;33:e29003. https://doi.org/10.18471/rbe.v33.29003

35. Dubar C. [The construction of self through work activity: the professional socialization]. Cad Pesqui. 2012;42(146):351-67. https://doi. org/10.1590/S0100-15742012000200003 Portuguese.

36. Macedo RM. [Resistance and resignation: gender narratives in the choice of nursing and education]. Cad Pesqui. 2019;49(172):54-76. https:// doi.org/10.1590/198053145992 Portuguese. 